Canadian Studies in Population, Vol. 30(1), 2003, pp. 221-240

\title{
Childhood Family Experience and Completed Fertility
}

\author{
Zheng Wu \\ Christoph M. Schimmele \\ Department of Sociology \\ University of Victoria \\ Victoria, British Columbia, Canada
}

\begin{abstract}
Understanding fertility change has been one of the most challenging tasks for population researchers. This paper contributes to our knowledge of fertility differentials by investigating if there is a relationship between family structure and completed fertility, and whether this relationship is modified by first birth experience. Our results show that coming from an intact family significantly lowers completed fertility. The relationship between family structure and completed fertility does not change with first birth experience.
\end{abstract}

Key Words: Fertility, completed fertility, family structure

Résumé

Understanding fertility change has been one of the most challenging tasks for population researchers. This paper contributes to our knowledge of fertility differentials by investigating if there is a relationship between family structure and completed fertility, and whether this relationship is modified by first birth experience. Our results show that coming from an intact family significantly lowers completed fertility. The relationship between family structure and completed fertility does not change with first birth experience.

Mots-clés: Fertility, completed fertility, family structure 
Zheng $W u$ and Christophe M. Schimmele

\section{Introduction}

The developed world has experienced a steady decline in fertility in recent decades. The scarcity of births has reached a point where below-replacement fertility is now commonplace throughout advanced, industrial societies. In 2000 , over 67 percent of all countries with stagnant or below-replacement fertility were located in the more developed regions (United Nations, 2001). Explaining below-replacement fertility has been a challenging task for demographers, especially since this trend was not anticipated. Although the locus of below-replacement fertility has never been precisely determined, it is generally understood that ideational and economic shifts (in conjunction with improved birth control methods) are the basic causes. These causes are conditioned by other social factors, however, and fertility varies in a commensurate manner. This paper contributes to our knowledge of micro-level fertility differentials by examining the relationship between family structure and completed fertility.

Family structure has important affects on children's life chances. The family plays a major role in determining individual economic status. The family economy shapes children's life chances because it determines their standard of living, the neighbourhood where they are raised, the quality of education they receive, etc. Furthermore, the family is a primary agent of socialization. Given this, we can reasonably expect that children raised in two-parent families will have different life chances than children raised in single-parent families. The consequences marital disruption and single-parenthood have on children in the short-term and over their lifetimes is well-known (Furstenberg and Cherlin, 1991; Thompson and Amato, 1999; Seltzer, 1994). The economic (Holden and Smock, 1991; McLanahan, Astone, and Marks, 1991; Mclean and Weitzman, 1991) and the social and psychological (Emery, 1999; McLanahan and Sandefur, 1994; Stevenson and Black, 1996) implications of divorce and singleparenthood have received considerable scholarly attention.

Child development studies have provided us with important insights into how family structure relates to things like school achievement (Astone and McLanahan, 1991), teenage pregnancy (Jacobs, 1994), and delinquency (Chen and Kaplan, 1997). Another important, though sparsely researched, issue is the relationship between childhood family experiences and lifetime fertility. Apart from being a biological occurrence, fertility is a social matter because it is conditioned by variables such as race, religion, birth cohort, social class status, and, of course, family structure. To isolate childhood and adolescent family experiences as a fertility differential is to ask how and why the family modifies fertility behaviour. These are important questions because they can explain how human reproduction is affected by intermediate factors like experiencing a parental divorce and growing up in a single-parent household. 
Childhood Family Experience and Completed Fertility

\section{Theoretical Background and Hypotheses}

To our knowledge, no study has established a clear association between family structure and completed fertility. However, related literature offers background information. Our study takes off from two previous streams of fertility research. We consider literature on the influence family structure has on early and premarital childbirth (McLanahan and Booth, 1989; McLanahan and Bumpass, 1988; Michael and Tuma, 1985; Thornton and Camburn, 1987; Trent, 1994; $\mathrm{Wu}, 1996 ; \mathrm{Wu}$ and Martinson, 1993) in conjunction with literature on how age and marital status at first birth affects completed fertility (Balakrishnan et al., 1988; Bumpass, Rindfuss, and Janosik, 1978; Morgan, 1996; Morgan and Rindfuss, 1999). Our empirical analysis integrates variables used in these streams of research to examine the relationship between family structure and completed fertility.

\section{Childhood Family Experience and Early/Premarital Childbirth}

Empirical evidence shows a strong association between non-intact family structure and early and premarital childbirth (McLanahan and Bumpass, 1988; Michael and Tuma, 1985; Thornton and Camburn, 1987; Trent, 1994; Wu and Martinson, 1993). Although studies confirm that being raised in a non-intact family increases a woman's chances of having early or premarital childbirth, the reasons behind this relationship are open to debate. The common theoretical explanations for this relationship focus on (1) economic deprivation in singleparent households, (2) the socialization process in single-parent households, and (3) family-stress associated with marital disruption and the single-parent household.

The economic deprivation hypothesis (Becker, 1981; Jencks, 1992; McLanahan, 1985; Wu, 1996) observes that single-parent households, and particularly mother-only households, are among the most susceptible to chronic poverty. McLanahan and Booth (1989) argue that perhaps the starkest difference between mother-only and two-parent households concerns economic well-being. About half of all mother-only families live below the poverty line compared to one in ten two-parent families.

As Becker $(1960,1981)$ observes, the desire for children competes with other opportunities such as educational attainment and employment. Hence, a woman's fertility behaviour is mediated by other opportunities available to her. In a study on teenage pregnancy, Cooksey (1990) shows that how teen pregnancies are resolved depends on socioeconomic status. For example, teenage women with highly educated parents are the least likely to carry their pregnancies to term because they realize that childbirth may disrupt their own educations and hurt their life chances. We can speculate that women from poorer socioeconomic backgrounds also calculate the costs of early and premarital childbirth in terms of their social class. Since economic deprivation obviously circumscribes educational and employment opportunities, poor women may feel 
they have less to lose from early childbirth. Jacobs (1994) argues that women who face limited opportunities for self-development often perceive motherhood as an escape from their situation and a means of establishing an adult identity. Simply put, the opportunity costs of children are relatively low for economically disadvantaged women, for whom motherhood may indeed be the most attractive (and accessible) opportunity available.

The socialization hypothesis (McLanahan and Bumpass, 1988; McLanahan and Booth, 1989; Thornton and Camburn, 1987; Thomson et al., 1994) emphasizes the impact of intergenerational effects on fertility behaviour. Evidence shows that being raised in a single-parent family is associated with forming one in later life (McLanahan, 1985; McLanahan and Bumpass, 1988). According to the socialization hypothesis, fertility is a learned behaviour and an adaptive response. Fertility is a learned behaviour because the experience of living in a single-parent household shapes attitudes concerning premarital sex, unwed motherhood, and marriage. Thornton and Camburn (1987) show that divorced mothers have more permissive attitudes toward premarital sex than is typical of two-parent households. Single mother's experiences (such as divorce, premarital childbirth, working outside the home) generally give them an appreciation of non-traditional gender roles. These less conventional attitudes may influence their children's perception about the risk (or undesirability) of early childbirth. Moreover, daughters of single-mothers may also learn that mother-only families are viable options, and thus may be less likely to perceive early and premarital motherhood in negative terms (McLanahan and Bumpass, 1988).

Fertility can be an adaptive response because economic circumstances may force daughters of single-mothers to assume adult responsibilities at an early age. As the economic deprivation hypothesis suggests, daughters from single-parent households may have to take on childcare duties (if they have younger siblings) since their mothers work outside the home and have little income to spare for paid childcare. These daughters may also have to find employment to supplement the household income. These circumstances may provide them with experiences that reduce the negative perception of single-parenthood. Women raised in single-parent households may have considerable parenting experience from taking care of their own siblings, and thus may not perceive having their own child as a major change or burden in their lives.

Finally, there is the family-stress hypothesis (Furstenberg and Cherlin, 1991; McLanahan, 1985; McLanahan and Booth, 1989; Wu, 1996). According to McLanahan and Booth (1989), mother-only families not only face poverty and economic insecurity, they are also affected by stress which accompanies divorce and low income. Changes in residence are common for divorced mothers, and this may involve adjustment to new neighbourhoods and disrupt former social networks. A divorce usually means less parental involvement in children's lives (ironically when they need it most) since parents move to separate residences and mothers have to work outside the home. The stress related to a residential move (changing schools, making new friends), reduced income, and less parental contact may compel children to seek emotional support outside the family. For female adolescents, this may increase their exposure to sexual 
relationships, which, in turn, raises the risk of early and premarital childbirth (Wu, 1996).

\section{The Timing of First Birth and Completed Fertility}

As we noted, there is a relationship between family structure and the risk of early and premarital childbirth. Both early and premarital childbirth have wellknown implications for completed fertility. Women's fertility is a time-limited event, possible only between menarche and menopause. This period is subject to biological restrictions (e.g., gestation and infecundable interval) that further limit total possible fertility (Morgan, 1996). Given these temporal limitations, the timing of first birth can be an important indicator of completed fertility. As Morgan and Rindfuss (1999) argue, since fertility is biologically the same for most women, those who begin their fertility careers early are likely to have higher subsequent fertility because they maximize their fecund period. For example, the postwar baby boom was partly a result that women began their childbearing careers at early ages.

Although this relationship has attenuated in recent decades because many women who started their fertility careers early also ended them early (Balakrishnan et al., 1988), a significant association remains between early and premarital childbirth and higher than average completed fertility. Using the Canadian Fertility Survey of 1984, Balakrishnan and his colleagues (1988) show that this trend was particularly salient for older birth cohorts. Among the women born in 1935-39, those who gave their first birth before age 18 had a total completed fertility of 4.71 births. By comparison, those women who waited until they were at least 25 had less than half this many births. For women born in 1955-59, these figures are 2.51 births and 2.08 births, respectively. Canada is not alone. Similar patterns have been observed in the United States (e.g., Morgan and Rindfuss, 1999), though there the relationship between timing of first birth and completed fertility has not attenuated to the degree that it has in Canada. Among American women born in 1935-39, those who had their first child at 17 or younger had a total completed fertility of 4.03 births. Those who waited until they were at least 25 had a total completed fertility of 2.25 births. For women born in 1950, these figures are 3.31 and 2.01 births, respectively.

\section{Childhood Family Experience and Completed Fertility}

Since the time-frame between menarche and menopause normally spans several decades between early adolescence and middle age, significant variation is possible in the timing of first birth, sequencing of subsequent births, and lifetime fertility. Social factors are responsible for most of this variation because women have similar levels of fecundity. Hence, it is important to identify what these factors are and explain how they affect fertility. There are good reasons to believe that family structure affects completed fertility. 
First, by examining the results of existing evidence, we can see an indirect relationship between family structure and completed fertility. As noted above, women raised in single-parent families have a higher risk of early or premarital pregnancy than women raised in two-parent families. Since both early and premarital childbirth are known to raise completed fertility, family structure should raise completed fertility through this relationship. However, we anticipate that family structure may also have a direct (or independent) effect on completed fertility.

Second, apart from gauging the risks of early and premarital pregnancy, the economic deprivation hypothesis also explains why non-intact family structure may raise completed fertility net of the effects of early and premarital childbirth. The reason being that since household income usually determines the quality of education children receive, people from poorer economic backgrounds are the least likely to have a high level of education or vocational training. These educational disadvantages affect their position in labour markets. People with little or no education beyond high school have little choice beyond low-paying employment with few benefits or opportunities for advancement. Whereas women with good educations and employment prospects typically delay entry into motherhood because for them the opportunity costs of children are high, the reverse may be true for women with few educational and employment opportunities. In other words, women from single-parent families may have no compelling reason to delay or limit their fertility because the economic circumstances in which they were raised provided them with inadequate alternatives to motherhood.

Third, besides influencing their chances of early or premarital pregnancy, the socialization process in single-parent families may also have a direct effect on completed fertility. A woman's experience of having been raised in a singleparent family may condition her perception of the opportunity costs of children. While rational choice theory tends to be an either or approach (i.e., a woman can have children or a career), witnessing their mothers balance family obligations and childcare with employment outside the home may influence daughters of single-mothers to believe that childbirth is not necessarily a major opportunity cost. Since women from single-parent families often gain work and childcare experience at an early age by helping their mothers cope, perhaps they are wellsuited to managing motherhood with other opportunities.

Using recent Canadian data, the principal objective of this study is to elucidate how family structure affects lifetime fertility. In anticipation of our empirical findings, we expect that, all else being equal, family structure does indeed affect completed fertility. We expect that being raised in a single-parent family will raise completed fertility. Besides investigating the direct relationship between family structure and completed fertility, we also ask if any intermediate variables condition this relationship. Specifically, we want to know if the effects of childhood family experiences are modified by first birth experience, i.e., early or premarital childbirth. 
Childhood Family Experience and Completed Fertility

\section{Data and Methods}

\section{Data}

Our empirical analysis uses data from the 10th round of the General Social Survey (GSS), conducted by Statistics Canada in 1995. The GSS-95 is a nationally representative sample of 10,749 people aged 15 and over, excluding residents of the Yukon and Northwest Territories, First Nations peoples living on reserves, and full-time institutionalized residents. Data for the GSS-95 were collected monthly from January 1995 to December 1995. The sample was evenly distributed over the 12 months to represent the seasonal variation. The data were collected by telephone interviews. Households without telephones were therefore excluded; however, there were less than $2 \%$ of such households in the target population. Survey estimates have been weighted to account for persons without telephones. The overall response rate was $81 \%$ (Statistics Canada, 1997).

Our study sample is restricted to women 45 and older who gave at least one live birth. Younger age cohorts are excluded because they remained in their fecund years and therefore had not completed their potential fertility. While biologically possible, childbearing after age 45 is an extremely rare event. In 1996, Canadian Vital Statistics reported that only 210 live births, or $0.057 \%$ of total live births, were born to women aged 45 and older (Duchesne et al., 1999: 22). Since virtually all women complete their childbearing years by age 45 , the problem of right-censoring is minimal. We limit our analysis to women who ever gave live births for two reasons. First, we want to ensure that the women in the study sample were fertile and that fertility regulation was largely a result of rational decisions, although we recognize that involuntary sterilization increases with age (e.g., Menken, 1985). Second, childless women are obviously not relevant to our analysis because one objective of our study is to investigate how childhood family experiences may influence the relationship between the timing of first birth and completed fertility. Further, although the study sample includes a subset of the original sample, there is no reason to believe that our sample selection introduces biases in regression estimates reported in this study.

\section{Measures}

Our dependent variable is completed fertility, which we measure as the total number of live births occurring (children ever born) to the respondent. Table 1 presents the descriptive statistics for the dependent variable and explanatory variables used in the study. The women in the study sample had a completed fertility totalling three children on average.

We use two variables to operationalize childhood family experiences. We use a dichotomous variable to indicate whether the respondent "always lived with" her parents up to age 15 . Table 1 shows that $88 \%$ of women grew up in an "intact family". We use one self-reported measure of childhood satisfaction based on 
Table 1

Definitions and Descriptive Statistics for Variables Used

in the Analysis of Lifetime Fertility for Canadian Women Aged 45 and Over, 1995

\begin{tabular}{|c|c|c|c|}
\hline Variable & Definition & Mean or \% & S. D. \\
\hline Children ever born & Number of live births & 3.20 & 1.86 \\
\hline Intact family & $\begin{array}{l}\text { Whether respondent lived with both parents up } \\
\text { to age } 15(1=\text { yes, } 0=\text { no })\end{array}$ & $87.8 \%$ & - \\
\hline Had a happy childhood & $\begin{array}{l}\text { Whether respondent had a happy childhood } \\
(1=\text { strongly disagree, } \ldots, 5=\text { strongly agree })\end{array}$ & 3.98 & 0.87 \\
\hline Age at first birth & Age at first birth in years & 25.75 & 5.43 \\
\hline Nonmarital (first) birth & First birth was premarital & $9.1 \%$ & - \\
\hline Years of marriage & Years of marriage up to age 45 & 19.03 & 7.97 \\
\hline $\begin{array}{l}\text { Age cohort } \\
1940-50 \\
1930-39 \\
1920-29 \\
<1920\end{array}$ & $\begin{array}{l}\text { Dummy indicator }(1=\text { yes, } 0=\text { no }) \\
\text { Dummy indicator }(1=\text { yes, } 0=\text { no }) \\
\text { Dummy indicator }(1=\text { yes, } 0=\text { no }) \\
\text { Reference group }\end{array}$ & $\begin{array}{l}36.4 \% \\
26.0 \% \\
22.4 \%\end{array}$ & $\begin{array}{l}- \\
-\end{array}$ \\
\hline Number of siblings & Number of full siblings & 3.96 & 2.79 \\
\hline Educational status & $\begin{array}{l}\text { Educational attainment in } 10 \text { levels }(1=\text { no } \\
\text { schooling, } \ldots, 10=\text { bachelor or higher })\end{array}$ & 5.23 & 2.79 \\
\hline Years of employment & Years of labor force participation up to age 45 & 3.71 & 7.78 \\
\hline $\begin{array}{l}\text { Religion } \\
\text { Protestant } \\
\text { Other religions } \\
\text { None } \\
\text { Catholic }\end{array}$ & $\begin{array}{l}\text { Dummy indicator }(1=\text { yes, } 0=\text { no }) \\
\text { Dummy indicator }(1=\text { yes, } 0=\text { no }) \\
\text { Dummy indicator }(1=\text { yes, } 0=\text { no }) \\
\text { Reference category }\end{array}$ & $\begin{array}{r}40.4 \% \\
3.6 \% \\
13.6 \%\end{array}$ & $\begin{array}{l}- \\
-\end{array}$ \\
\hline $\begin{array}{l}\text { Region } \\
\text { Quebec } \\
\text { Rest of Canada }\end{array}$ & $\begin{array}{l}\text { Dummy indicator }(1=\text { yes, } 0=\text { no }) \\
\text { Reference category }\end{array}$ & $25.1 \%$ & - \\
\hline$N$ & & 2,201 & \\
\hline
\end{tabular}

Source: 1995 General Social Survey.

Note: Weighted means or percentages, unweighted N. 
five-point ordinal scale responses to the statement, "I had a happy childhood". The mean value for the measure indicates that most respondents reported that they had a happy childhood.

We argued that childhood family experiences might shape fertility behaviour in early adulthood and subsequently characterize lifetime fertility. We examine two variables that can determine completed fertility. One is age at first birth. The other indicates if the first birth was out-of-wedlock. Table 1 shows that the average age at first birth was almost 26 , and $9 \%$ of first births were out-ofwedlock.

Following prior studies (e.g., Balakrishnan, Lapierre-Adamcyk, and Krótki, 1993; Davis, Bernstam, and Ricardo-Campbell, 1986), we include several demographic and socioeconomic variables known to affect completed fertility:

(1) We use the amount of time spent in marriage as an "exposure" variable. It measures the total number of years spent in marriage up to age 45 , including all marriages up to the seventh union. Given that nonmarital cohabitation was uncommon for the women in the study sample (Wu, 2000), we did not consider time spent in cohabitations unless the marriage in question was preceded by nonmarital cohabitation. When this was the case, the time spent in marriage begins from the onset of nonmarital cohabitation. We anticipate that greater exposure to marriage will raise completed fertility.

(2) The long-term decline in Canadian fertility partly reflects a change in preference for family size over succeeding generations (Balakrishnan and $\mathrm{Wu}, 1992$; Ryder, 1965). We use birth cohort to capture some of this change. We expect that women born in early cohorts will have higher fertility than women born in recent cohorts.

(3) The intergenerational impact of family behaviour is well-known (Axinn, Clarkberg, and Thornton, 1994; Axinn and Thornton, 1996). We use the number of siblings as a measure of mother's fertility, and anticipate that a woman's fertility may parallel the number of siblings she has.

(4) We consider two economic indicators: educational attainment and labour force participation. Prior research has shown that education is perhaps the most consistent determinant of fertility, and its negative effect is well-documented (e.g., Hirschman, 1994; Bulatao and Lee, 1983). Education is measured using a 10-level ordinal scale that ranges from elementary school education or less to a bachelor's degree or higher. We anticipate that increases in education will have a negative influence on completed fertility. We use time spent in the waged-labour up to age 45 as an indicator of labour force participation. Similar to education, we presume that greater labour force participation reduces lifetime fertility because opportunity costs 
Zheng $W u$ and Christophe M. Schimmele

intensify as employment status, job prestige, and earning power improve.

(5) We include two social indicators. Religion is a multinomial variable in four levels: a) Catholic, b) Protestant, c) other religion, and d) no religious orientation. Even though the positive relationship between religion and fertility behaviour has attenuated in recent years (Balakrishnan and Chen, 1990), religion continues to structure family behaviour in crucial ways (e.g., Lehrer, 1996; Lehrer and Chiswick, 1993). We use Catholics as a reference group, comparing and contrasting Catholic fertility with those of other religious denominations and those without religious orientation. Region factors as a dichotomy that indicates if the respondent is a Quebec or non-Quebec resident. We separate Quebec from the other provinces and territories because, as Beaujot and McQuillan (1982) argue, the "French-English dualism" has been an especially distinctive cultural, political and demographic feature of Canadian history (also see Pollard and $\mathrm{Wu}, 1998)$.

\section{The Statistical Model}

For the purpose of this paper, we assume that completed fertility follows a Poisson distribution with a conditional mean that depends on observed individual characteristics (McCullagh and Nelder, 1989). Specially, the Poisson model of fertility can be written as

$$
\ln \left(\lambda_{\mathrm{i}}\right)=\ln \left[E\left(\lambda_{\mathrm{i}} \mid \mathbf{x}_{\mathrm{i}}\right)=\beta^{\prime} \mathbf{x}_{\mathrm{i}}\right.
$$

where $\lambda_{\mathrm{i}}$ is a vector of expected values, $\beta$ is the parameter vector, $\mathbf{x}_{\mathrm{i}}$ is a vector of explanatory variables. Although $\beta$ indicates the effects of the explanatory variables, a simple transformation of $\beta$ gives a more meaningful interpretation. For example, a transformation of $\beta_{\mathrm{j}}, 100 \times\left[\exp \left(\beta_{\mathrm{j}}\right)-1\right]$ indicates the percentage change in the expected count (fertility) for a one unit change in $\mathrm{x}_{\mathrm{j}}$, controlling for other explanatory variables (Long, 1997: 225). The effect of a dichotomous variable is obtained by letting $\mathrm{x}_{\mathrm{j}}$ change from 0 to 1 .

\section{Results}

Our empirical analysis begins with replicating the prior studies that examine the relationship between early childhood experience and premarital/teenage births (e.g., Wu, 1996; Wu and Martinson, 1993). Table 2 shows the results of generalized linear models (GLM, McCullagh and Nelder, 1989), using age at first birth and nonmarital first birth as dependent variables and each of the two childhood experiences as independent variables. We present the results with and without control variables. 


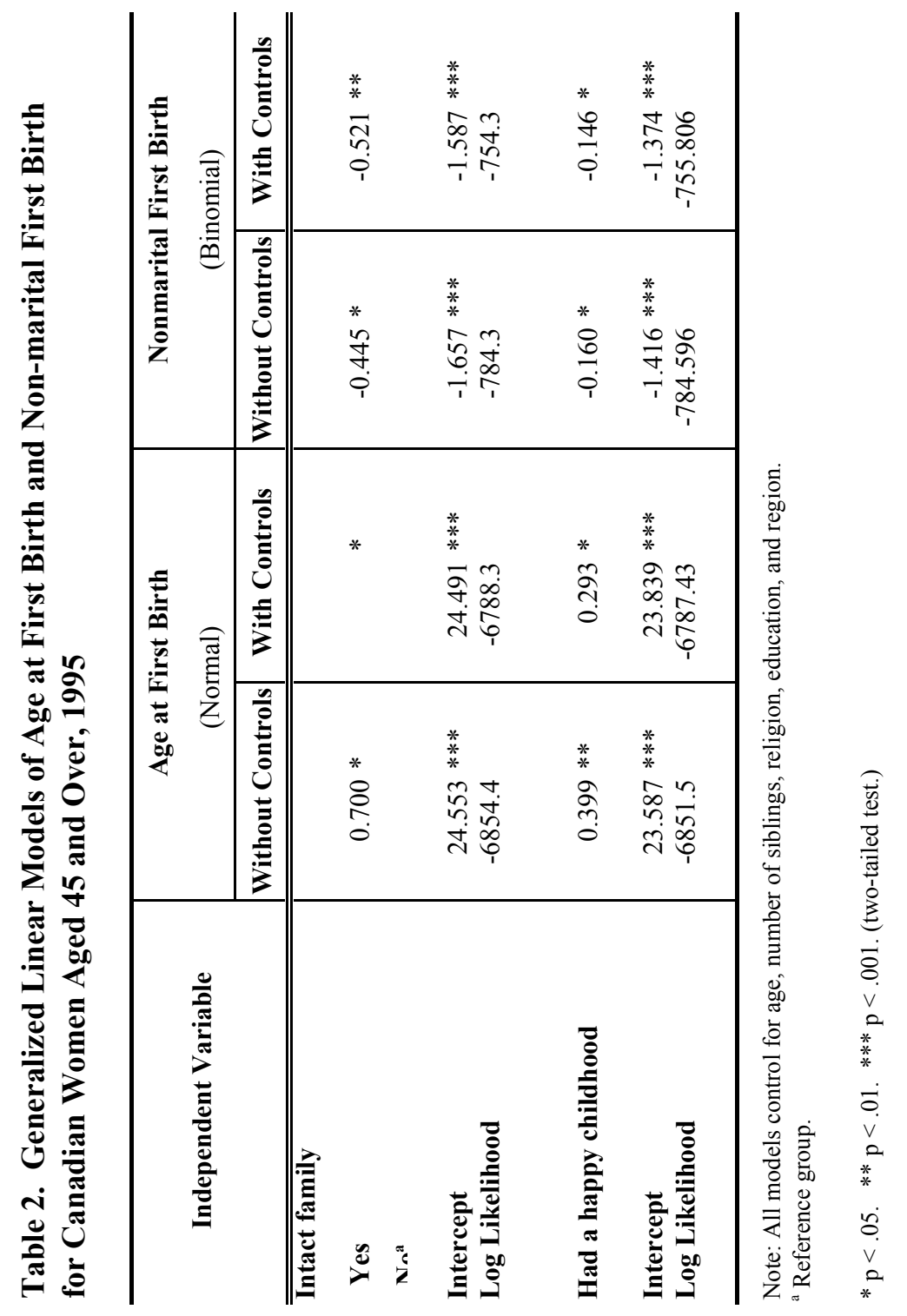


The results in Table 2 are consistent with prior studies. We note that women raised in intact families tend to give their first birth at an older age and that their child is more likely to be born within marriage than women raised in broken (single-parent) families. A similar relationship is observed for women who report that they had a happy childhood. The strengths of these relationships remain virtually unchanged when control variables are added. In short, our results show that favourable childhood experiences tend to delay entry into motherhood and reduce the likelihood of out-of-wedlock birth.

We now turn to lifetime fertility. Again, we begin with the bivariate model with both childhood family experience and early life event variables as the sole explanatory variable. We then combine these models and add controls to the model. Finally, we add interaction terms between the childhood variables and early fertility experience variables to test the hypothesis that the effects of childhood experiences may change with fertility experience in early adulthood. Table 3 presents the results of the Poisson regressions of lifetime fertility.

We see that among four the bivariate analyses, only age at first birth is significant (see models 1-4). Model 5 combines models 1-4 and adds control variables. Model 6 adds the interaction terms, and shows that none of the interaction terms is statistically significant. Indeed, in model 6 , the effects of the independent variables become nonsignificant. These results suggest that model 5 is properly specified, and thus it is our preferred model. Rejecting the interaction model also nullifies the hypothesis that the effects of childhood experiences on lifetime fertility change with fertility experience in early adulthood.

Model 5 in Table 3 shows that, with control variables added, coming from an intact family becomes statistically important $(p<.01)$. Growing up in an intact family reduced expected fertility by $9 \%\left(100 \times\left[\mathrm{e}^{-0.091}-1\right]\right)$. However, the effect of "happy childhood" is not statistically significant. Overall, our results are consistent with the hypothesis that adverse childhood experiences may increase completed fertility.

Model 5 also shows that age at first birth remains negative and highly significant. The negative effect of age at first birth confirms the finding of early studies on the relationship between the timing of first birth and lifetime fertility (e.g., Morgan, 1996; Morgan and Rindfuss, 1999). Nonmarital first birth also is a significant factor. We find that lifetime fertility is $8 \%$ higher for women whose first child was born out-of-wedlock than for those whose first child was born in marriages.

The effects of other variables are generally consistent with our expectations. First, model 5 in Table 3 shows that exposure to marriage has a positive effect on fertility. For example, a ten-year increase in the duration of marriage raised completed fertility by $10 \%$. This finding supports the view that increased exposure to a male partner raises fertility. However, we are aware that the rate of increase is unlikely to be consistent through the childbearing years (normally age 15-45), and that the effect would normally be more pronounced during the 
Table 3

Possion Regressions of Lifetime Fertility (CEB) on Childhood Family Characteristics and Early Childbearing Experiences for Canadian Women Aged 45 and Over, 1995

\begin{tabular}{|c|c|c|c|c|c|c|}
\hline Independent Variable & Model 1 & Model 2 & Model 3 & Model 4 & Model 5 & Model 6 \\
\hline \multicolumn{7}{|l|}{$\overline{\overline{\text { Intact family }}}$} \\
\hline $\begin{array}{l}\text { Yes } \\
\text { Noa }\end{array}$ & -0.028 & & & & $-0.091 * *$ & -0.002 \\
\hline $\begin{array}{l}\text { Had a happy childhood } \\
\text { Age at first birth }\end{array}$ & & 0.002 & $-0.021 * * *$ & & $\begin{array}{l}-0.010 \\
-0.013 * * *\end{array}$ & $\begin{array}{l}-0.040 \\
-0.016\end{array}$ \\
\hline $\begin{array}{l}\text { Nonmarital (first) birth } \\
\text { Yes } \\
\text { Noa } \\
\text { Years of marriage }\end{array}$ & & & & 0.037 & $\begin{array}{l}0.081 * \\
0.010 * * *\end{array}$ & $\begin{array}{l}0.194 \\
0.010^{* * * *}\end{array}$ \\
\hline $\begin{array}{l}\text { Age cohort } \\
1940-50 \\
1930-39 \\
1920-29 \\
<1920 \text { a }\end{array}$ & & & & & $\begin{array}{l}-0.325 * * * \\
-0.050 \\
0.017\end{array}$ & $\begin{array}{l}-0.325 * * * \\
-0.051 \\
0.015\end{array}$ \\
\hline Number of siblings & & & & & $0.035^{* * *}$ & $0.035 * * *$ \\
\hline Educational status & & & & & $-0.022 * * *$ & $-0.022 * * *$ \\
\hline Years of employment & & & & & $-0.004 *$ & $-0.004 *$ \\
\hline $\begin{array}{l}\text { Religion } \\
\text { Protestant } \\
\text { Other religions } \\
\text { None } \\
\text { Catholica }\end{array}$ & & & & & $\begin{array}{l}-0.103 * * * \\
-0.074 \\
-0.126 * *\end{array}$ & $\begin{array}{l}-0.103 * * * \\
-0.074^{* *} \\
-0.127^{* *}\end{array}$ \\
\hline $\begin{array}{l}\text { Region } \\
\text { Quebec } \\
\text { Rest of Canada }\end{array}$ & & & & & -0.031 & -0.031 \\
\hline $\begin{array}{l}\text { Interactions } \\
\text { Intact family ' age at first birth }\end{array}$ & & & & & & -0.003 \\
\hline Happy childhood ' age at first birth & & & & & & 0.001 \\
\hline Intact family ' nonmarital birth & & & & & & -0.115 \\
\hline Happy childhood ' nonmarital birth & & & & & & -0.004 \\
\hline $\begin{array}{l}\text { Intercept } \\
-(\sigma \chi \alpha \lambda \varepsilon \pi \alpha \rho \alpha \mu \varepsilon \tau \varepsilon \rho) \\
\text { Log Likelihood }\end{array}$ & $\begin{array}{r}1.236 * * * \\
1.046 \\
1427.1\end{array}$ & $\begin{array}{l}1.205^{* * *} \\
1.047 \\
1426.5\end{array}$ & $\begin{array}{r}1.744^{* * *} \\
1.026 \\
1529.3\end{array}$ & $\begin{array}{r}1.207^{* * *} \\
1.046 \\
1427.5\end{array}$ & $\begin{array}{l}1.579 \text { *** } \\
0.925 \\
2143.6\end{array}$ & $\begin{array}{r}1.6211^{* * *} \\
0.925 \\
2142.8\end{array}$ \\
\hline
\end{tabular}

a Reference group.

${ }^{*} \mathrm{p}<.05 .{ }^{* *} \mathrm{p}<.01 .{ }^{* * *} \mathrm{p}<.001$. (two-tailed test.) 
prime fecund years, i.e., under age 30 . We also recognize that childbearing is not limited to marriages and that the proportion of nonmarital births have increased in recent decades, particularly in Quebec (e.g., Duchesne et al., 1999: 29).

Second, Table 2 shows the differential effects of age cohort on fertility trends. Women born in the 1940s had significantly lower levels of fertility than those born in or before 1920, which is consistent with the long-term decline in Canadian fertility. In terms of completed fertility, women born in the 1920s and 1930s are not significantly different from women born in or before 1920. This pattern is consistent with the aggregate fertility trend in the 20th century (Balakrishnan and $\mathrm{Wu}, 1992$ ). Women who were born in the 1920s and 1930s were in their prime childbearing ages in the late 1940s and 1950s (a period of post-war prosperity) and gave birth to the baby-boom generation. And as is now well-known, the boomer generation experienced a baby bust.

Third, the number of siblings a mother has affects her completed fertility. As expected, an increase in the number of siblings raises completed fertility. This finding supports the notion that parental fertility behaviour has a long-term impact on offspring's fertility outcomes.

Fourth, the effects of education and labour force participation are also consistent with our expectations. A one unit increase in the level of education reduces completed fertility by about $2.2 \%$. Compared to elementary school education, a college education reduces a woman's (expected) fertility by $22 \%$, net of the influences of other variables. Labour force participation has a similar impact, although its magnitude is much less dramatic. A ten-year increase in labour force participation reduces a woman's fertility by only $4 \%$. These results support the notion that the decline in fertility partly reflects the overall increase in the level of education and women's labour force participation.

Fifth, religion has a significant effect on completed fertility. Table 3 indicates that Catholic women have higher levels of fertility than Protestants and those who have no religious orientation. Catholic women do not differ significantly from women who have other religious faiths. The impact of Catholicism on fertility seems to be inconsistent with recent Canadian fertility studies that found its impact minimal (e.g., Balakrishnan and Chen, 1990). However, this contradiction may be superficial because our target population includes older cohorts of women (those who were born in or before 1950), whereas the target of population in Balakrishnan and Chen's study includes young and old women. Our finding is congruous with the high level of fertility observed in Catholics, particularly those in the province of Quebec, decades ago. Indeed, regional differences in fertility more or less fade out when religion is controlled for, and this specifies the governing influence Catholicism has on fertility. 


\section{Discussion and Conclusion}

For the past several decades, fertility decline has been a common experience throughout the more developed world. This trend has been a salient issue in demographic studies because it has reached a point where many developed countries are now failing to replace their populations. The reasons for this scarcity of births are complex, but ideational and economic transformations seem particularly important. Family size preferences have gradually decreased as the opportunity costs of children have risen. Since the 1960s, social and political changes associated with the women's movement have opened doors for women. The women of the baby boom generation received a higher education than previous generations, and this paid dividends in labour markets. With their comparatively high earning power, boomer women were less likely than to abandon their careers for early marriage and motherhood than their mothers were. This notion is supported by the fact that the boomers delayed entry into marriage and motherhood.

Although below-replacement fertility is a temporal phenomenon, the intensity of fertility decline has been tempered by other factors. Fertility has a biological component (fecundity) that is more or less the same for all women, and it has a social component that accounts for differentiation between women. The motivations behind childbearing are contingent on race, socioeconomic status, and religion, among other things. Another important fertility differential is family structure. Despite the wealth of fertility literature available - the Population Index lists over 14,000 documents for the past two decades alone very little is known about the relationship between family structure and completed fertility. Our study has aimed to reduce this gap in the literature.

The principal objective of our study has been to examine the effects childhood and early adolescent family experiences have on completed fertility. In addition, we investigated if the effects of first birth experience modify the relationship between family structure and completed fertility. Prior studies have shown the linkage between family structure and women's chances of early and premarital childbirth, and also how age and marital status at first birth affects sequencing of subsequent births and completed fertility. Although we can logically deduce that family structure affects completed fertility through its influence on age and marital status at first birth, no study has examined if there is a direct connection between family structure and completed fertility.

Our study examined family structure using two variables. Respondents in the study sample were asked if they lived with both parents up to age 15 , and they were asked to rank the happiness of their childhood on a five-point ordinal scale. The vast majority reported they were raised in a two-parent family and that they had a happy childhood (see Table 1). As expected, our analysis shows that coming from an intact family significantly raises a woman's age at first birth and lowers her risk of non-marital first birth (see Table 2). Hence, we were correct to argue that childhood and early adolescent family experiences may have an indirect effect on completed fertility. 
However, the effects of family structure could be circumscribed because of data limitations. Bear in mind that the GSS-95 asked respondents if they lived with both parents before age 16. This may be an important detail considering that the family-stress hypothesis emphasizes the immediate (or short-term) implications marital disruption has on the risk of adolescent premarital childbirth. Since exposure to sexual intercourse is obviously greater after age 15 than before, we can reasonably assume that divorce-related stress would have had a more pronounced effect on women's fertility when it occurred after they were 15 . Hence, the impact of non-intact family structure on early and premarital childbirth (and thereby completed fertility) may be more significant than our results indicate.

Turning now to our main objective, we found that, net of all other effects, childhood family experiences affect completed fertility. Both being raised in a two-parent family significantly reduced completed fertility (see Table 3). Although we intuitively assumed that the relationship between family structure and completed fertility would be modified by age and marital status at first birth, this was not the case. The effects of early and premarital childbirth raise completed fertility to the same degree for women from intact families as they do for women from non-intact households. While no interaction effects are present, the effects of family structure may well accumulate with the effects of age and marital status at first birth because women from broken homes have the highest risk of giving early and premarital childbirth.

Even though Canada now faces below-replacement fertility, the higher completed fertility observed in women from unfavourable family backgrounds may have negative social and political consequences that outweigh the demographic benefits. Since early and premarital births often limit educational and employment opportunities, they can lock poor women into their socioeconomic class (McLanahan, 1985; McLanahan and Booth, 1989). Hence, early/premarital fertility can be a mediating factor in the reproduction of poverty. Besides constraining the mother's options, early/premarital childbirth reproduces circumstances that increase the probability that her children will give early/premarital birth. The intergenerational effects are not trivial, and many studies have noted that women from single family households are indeed at high risk of forming such households themselves (McLanahan and Bumpass, 1988; Thornton and Camburn, 1987; Trent, 1994; Wu, 1996; Wu and Martinson, 1993). The proliferation of disadvantaged households (and the feminization of poverty) can, ironically, re-emerge in context of how disadvantaged women respond to their social and economic circumstances. If higher completed fertility is the result of poverty, then, despite below-replacement fertility, the best course of action is perhaps policies that give women from disadvantaged backgrounds options apart from motherhood. 
Childhood Family Experience and Completed Fertility

\section{Acknowledgements:}

The authors gratefully acknowledge financial support from Canadian Institute for Health Information (CIHI) grant. Additional research support was provided by the Department of Sociology, University of Victoria. Direct all correspondence to Zheng $\mathrm{Wu}$, Department of Sociology, the University of Victoria, P. O. Box 3050, Victoria, British Columbia, V8W 3P5 Canada.

E-mail: zhengwu@uvic.ca

\section{References:}

Astone, N. M. and S. McLanahan. 1991. "Family structure, parental practices, and high school completion," American Sociological Review 56: 309-20.

Axinn, W. G., M. E. Clarkberg, and A. Thornton. 1994. "Family influences on family size preferences,” Demography 31: 65-79.

Axinn, W. G. and A. Thornton. 1996. "The influence of parents' marital dissolutions on children's attitudes toward family formation," Demography 33: 66-81.

Balakrishnan, T. R. and J. Chen. 1990. "Religiosity, nuptiality and reproduction in Canada," Canadian Review of Sociology and Anthropology 27: 316-40.

Balakrishnan, T. R., K. V. Rao, K. J. Krótki, and E. Lapierre-Adamcyk. 1988. "Age at first birth and lifetime fertility," Journal of Biosocial Science 20: $167-74$.

Balakrishnan, T. R., E. Lapierre-Adamcyk, and K. J. Krótki. 1993. Family and Childbearing in Canada: A Demographic Analysis. Toronto: University of Toronto Press.

Balakrishnan, T. R. and Z. Wu. 1992. "Regional pattern of nuptiality and fertility in Canada: 1921-1986," Genus 48: 151-171.

Beaujot, R. and K. McQuillan. 1982. Growth and Dualism: The Demographic Development of Canadian Society. Toronto: Gage.

Becker, G. S. 1981. A Treatise on the Family. Cambridge, Mass.: Harvard University Press.

Becker, G. S. 1960. "An economic analysis of fertility," in National Bureau of Economic Research, Demographic and Economic Change in Developed Countries. Princeton: Princeton University Press. 209-31. 
Zheng $W u$ and Christophe M. Schimmele

Bulatao, R. A. and R. D. Lee (eds.). 1983. Determinants of Fertility in Developing Countries. New York: Academic Press.

Bumpass, L. L., R. R. Rindfuss, and R. B. Janosik. 1978. "Age and marital status at first birth and the pace of subsequent fertility," Demography 15: $75-86$.

Chen, Z. and H. B. Kaplan. 1997. "The impact of family structure during adolescence on deviance in early adulthood," Deviant Behavior 18: 365-91.

Cooksey, E. C. 1990. "Factors in the resolution of adolescent premarital pregnancies," Demography 27: 207-18.

Davis, K., M. S. Bernstam, and R. Ricardo-Campbell (eds.). 1986. Belowreplacement Fertility in Industrial Societies: Causes, Consequences, and Policies. Population and Development Review. 12 (supplement).

Duchesne, D., F. Nault, H. Gilmour, and R. Wilkins. 1999. Vital Statistics Compendium, 1996. Catalogue no. 84-214-XIE. Ottawa: Statistics Canada.

Emery, R. E. 1989. Marriage, Divorce, and Children's Adjustment. Newbury Park: Sage Publications.

Furstenberg, F. F. and A. J. Cherlin. 1991. Divided Families: What Happens to Children When Families Part. Cambridge, Mass.: Harvard University Press.

Hirschman, C. 1994. "Why fertility changes," Annual Review of Sociology 20: 203-33.

Holden, K. C. and P. J. Smock. 1991. "The economic costs of marital dissolution: Why do women bear a disproportionate cost?" Annual Review of Sociology 17: 51-78.

Jacobs, J. L. 1994. "Gender, race, class, and the trend toward early motherhood," Journal of Contemporary Ethnography 22: 442-62.

Jencks, C. 1992. Rethinking Social Policy: Race, Poverty, and the Underclass. Cambridge, Massachusetts: Harvard University Press.

Lehrer, E. L. 1996. "Religion as a determinant of marital fertility," Journal of Population Economics 9: 173-96.

Lehrer, E. L. and C. U. Chiswick. 1993. "Religion as a determinant of marital stability," Demography 30: 385-404. 
Long, J. S. 1997. Regression Models for Categorical and Limited Dependent Variables. Thousand Oaks: Sage.

McLanahan, S. 1985. "Family structure and the reproduction of poverty," American Journal of Sociology 90: 873-901.

McLanahan, S., N. M. Astone, and N. F. Marks. 1991. "The role of motheronly families in reproducing poverty," in A. C. Huston (ed.), Children in Poverty: Child Development and Public Policy. Cambridge: Cambridge University Press.

McLanahan, S. and K. Booth. 1989. "Mother-only families: Problems, prospects, and politics," Journal of Marriage and the Family 51: $557-80$.

McLanahan, S. and L. Bumpass. 1988. "Intergenerational consequences of family disruption," American Journal of Sociology 94: 130-52.

McLanahan, S. and G. Sandefur. 1994. Growing Up With a Single Parent: What Hurts, What Helps. Cambridge, Mass.: Harvard University Press.

Maclean, M. and L. J. Weitzman (eds.) 1992. Economic Consequences of Divorce: The International Perspective. Oxford: Clarendon Press.

McCullagh, P. and J. A. Nelder. 1989. Generalized Linear Models. Second edition. London: Chapman and Hall.

Menken, J. 1985. “Age and fertility: How late can you wait?" Demography 22: 469-483.

Michael, R. T. and N. B. Tuma. 1985. "Entry into marriage and parenthood by young men and women: The influence of family background," Demography 22: 515-44.

Morgan, S. P. 1996. "Characteristic features of modern American fertility," in J. B. Casterline, R. D. Lee, and K. Foote (eds.), Fertility in the United States: New Patterns, New Theories. New York: The Population Council.

Morgan, S. P. and R. R. Rindfuss. 1999. "Reexamining the link of early childbearing to marriage and to subsequent fertility, Demography 36: $59-75$.

Pollard, M. S. and Z. Wu. 1998. "Divergence of marriage patterns in Quebec and elsewhere in Canada," Population and Development Review 24: 329-356. 
Zheng $W u$ and Christophe M. Schimmele

Ryder, N. B. 1965. "The cohort as a concept in the study of social change," American Sociological Review 30: 843-61.

Seltzer, J. A. 1994. "Consequences of marital dissolution for children," Annual Review of Sociology 20: 235-66.

Statistics Canada. 1997. Public Use Microdata File Documentation and User's Guide - 1995 General Social Survey - Cycle 10. Catalogue no. 12M0010GPE. Ottawa: Statistics Canada.

Stevenson, M. R. and K. N. Black. 1996. How divorce Affects Offspring: A Research Approach. Boulder: Westview Press.

Thompson, R. A. and P. R. Amato (eds.). 1999. The Postdivorce Family: Children, Parenting, and Society. Thousand Oaks: Sage Publications.

Thomson, E., T. L. Hanson, and S. McLanahan. 1994. "Family structure and child well-being: Economic resources vs. parental behaviors," Social Forces 73: 221-42.

Thornton, A. and Donald Camburn. 1987. "The influence of the family on premarital sexual attitudes and behavior," Demography 24: 323-340.

Trent, K. 1994. "Family context and adolescents' fertility expectations," Youth and Society 26: 118-37.

United Nations. 2001. "World population prospects: The 2000 revision," mimeo.

Wu, L. L. 1996. "Effects of family structure and income on risks of premarital birth," American Sociological Review 61: 386-406.

Wu, L. L. and B. C. Martinson. 1993. "Family structure and the risk of a premarital birth," American Sociological Review 58: 210-32.

Wu, Z. 2000. Cohabitation: An Alternative Form of Family Living. Don Mills, Ontario: Oxford University Press. 